\title{
Several Aspects of Procedures in Kosovo Constitutional Court Regarding Fair Trial
}

\section{Uka $M^{*}$}

Faculty of Law, Pristina University, Kosovo

\section{Mini Review \\ Volume 3 Issue 3}

Received Date: August 28, 2020

*Corresponding author: Mirvete Uka, Faculty of Law, Pristina University, Kosovo, Rr. George Bush, Nr. 31, 10000 Prishtinë, Republic of Kosovo, Tel: +38138244183/244186, Fax: +38138244187; Email: mirveteuka@hotmail.com
Published Date: September 15, 2020

DOI: $10.23880 /$ abca-16000135

\section{Abstract}

Kosova is not a member of European Council and consequently as signatory of the European Convention for Human Rights and Freedoms, mainly its citizens cannot make complaints at the Court for Human Freedom and Rights in Strasbourg even when they claim that their rights are violated by Courts or other Institutions in Kosovo. Therefore the final authority that deals with these claims is Constitutional Court which its decisions bases on practice of European Court for Protection of Human Rights and Freedoms. Kosovo citizens more and more are using this right and are directing to the Constitutional Court in cases when they claim that their rights are violated.

Keywords: Kosovo Constitutional Court; Human Rights; Fair Trial; ECHR

\section{Introduction}

The Constitutional Court of Republic of Kosovo was established in January 2009. Due to the specifics of the youngest state in Europe, Constitutional Court is the final authority in the Republic of Kosovo for interpretation of the Constitution and compatibility of laws with the Constitution. It is completely independent institution in carrying out her responsibilities. The legal architecture is generally based on the principle of constitutional supremacy, which means that the constitution represents a lex fundamentalist in a constitutional democracy. This principle means that any law or legal act contrary to constitutional provisions is considered invalid and null [1]. The Constitutional Court decides only on cases brought before the Court legally by the authorized party even if the authorized party has withdrawn from the procedure.

Principle of citizen's equality is valid as a legal principle that is the legal right is provided, equality before the law and according to law. Such a constitutional principle is not allowed to be violated by ordinary laws. From this principle it follows that those who enforce laws, that are the constitutional power, must apply them equally to all, and offers the same protection to everyone. According to the principle of citizen equality, it would never be possible to issue any special law or create any privilege for others [2]. Before considering a request, it first assesses whether it has met the procedural criteria for admissibility set out in the Constitution and further specified in the Law and Rules of Procedure. The court acts only on the basis of law but not ex officio ${ }^{1}$. The Court is an independent body for the protection of the Constitution and for ensuring respect for diving of powers and the rule of law. The headquarters of the Constitutional Court is located in Prishtina. It holds hearings at its headquarters, but exceptionally, with its decision may hold hearings in other cities of Republic of Kosovo². The Constitutional Court has its own symbol and seal which are defined by work rule.

The Constitutional Court consists of nine (9) judges,

1 Law on Constitutional Court No. 03/L-121)

2 Article 3, parag. 2 of Law on KCL. 
who will be prominent jurists and personalities with the highest morals, with not less than ten (10) years of relevant professional experience. Judges are appointed by the President of the Republic of Kosovo, on the proposal of the Assembly, for a nine-year term, without possibility of extension.

In performance of their judicial functions, judges are independent based to the law and their decisions should not be subject to any review outside the appeal procedures provided by law. Executive and legislative branches must ensure that judges are independent and that no steps are taken that would jeopardize independence of judges. It should also be noted that judges are independent in the interest of the public.

\section{Publicity of Trials and Work Transparency of Constitutional Court}

Work of the Court is transparent, open to the public and accessible to it, to the highest possible degree, in accordance with the Constitution, Law and criteria for maintaining confidentiality, including, but not limited to:

a) Informing the public about the date and time of hearings;

b) Providing information on the course of the procedure;

c) Allowing viewing of files and documents;

d) Publication of judgments and decisions as well as

e) Any other form of communication prescribed by the Court.

The Secretary-General shall publish judgments and decisions on the website of the Court, immediately after the adoption of their final text and shall ensure the regular publication of printed versions of judgments and decisions. If necessary, the Court may issue communiqués or hold press conferences. Press releases are issued by the Secretary General only after the content is approved by the President, while a copy of the press release is received by all judges and as soon as possible.

Hearings, including the announcement of judgments, are open to the public. But, as the ECHRF instructs, the right to a public trial is not absolute and therefore the Constitutional Court may decide to exclude the public when it deems it necessary to preserve:

a) State secret, public order or morality;

b) Confidential information which would be jeopardized by public review;

c) Privacy or business secret of the party to the proceedings.

But the Court's advises are not open to the public and will remain confidential. Meanwhile, regarding documentation of cases reviewed in Constitutional Court, parties have the right to look at the official files and documents for the case in which they are parties in the procedure, unless that file or that document is determined by the Court to be confidential. Report of the Reporting Judge, the draft decision of the Review Panel, any information on the discussion and voting of the judges, the draft decisions and any notes of the judges during the discussion and examination of the case, as well as other material determined by the Court, must be confidential and in it neither the parties nor the public will have access. The court may authorize the issuance of a confidential document, if it determines that such a thing is necessary for the public interest ${ }^{3}$.

\section{Parties Authorized to Initiate Proceedings at Constitutional Court}

Authorized parties to address the Constitutional Court are: Assembly of Kosovo, President of the Republic of Kosovo, Government and People's Advocate (Ombudsman), President of the Assembly, Municipalities, more than 10 deputies together, or more than 30 deputies in other cases, regular courts and individuals, when they claim that their freedoms and rights have been violated by public institutions. But individuals are authorized to raise violations by public authorities of their individual rights and freedoms, guaranteed by the Constitution, only after they have exhausted all legal means provided by law. In such cases, the time limit starts to run from the day when the applicant is served with the court decision. In all other cases, time limit shall run on the day on which the decision or act is publicly announced. If the request is directed against a law, then the deadline starts to run from the day the law came into force. Court considers that it cannot take into account applicant's allegations without supporting documents and material evidence, in accordance with Article 22.4 of the Law and rules 29 (2) (h) and 32 (5) of the Rules of Work.

\section{Request Specification}

For a claim to be considered by the Court and for which a decision on the merits of case to be made, the claim must be specified. Applicant has the duty to clarify in his request exactly which rights and freedoms he claims have been violated and what is the concrete act of the public authority which the applicant wants to challenge".

The burden of proof falls on the applicant, therefore if the applicant alleges that Supreme Court or any other regular court has violated his rights guaranteed by the Constitution and international conventions, he should refer to any constitutional provision in particular. On the contrary, the Constitutional Court finds that the applicant's request has not met the procedural criteria for further review due to the

3 Rule 23, parag. 3 of regulation of KCL. 
failure to complete the request with relevant documentation. But if the Court finds that the applicant has based his request on a violation of the Criminal Code and the Code of Criminal Procedure, then Court finds that what the applicant raises in the request is a matter of legality and not of constitutionality. In this regard, the Court emphasizes that it is not the duty of the Constitutional Court to deal with errors of fact or law (legality), which may be alleged to have been committed even by the Supreme Court, except that and to the extent that they may have violated the rights and freedoms protected by the Constitution (constitutionality).

The request submitted in accordance with article 113, paragraph 3 (5) of the Constitution, among others, presents the following information:

a) Description of the facts of the alleged violation;

b) Concrete provisions of the Constitution which are allegedly violated and

c) The presentation of evidence on which the allegation of constitutional violation is based ${ }^{4}$.

Thus, every individual has the right to seek legal protection from the Constitutional Court if he claims that his individual rights and freedoms guaranteed by the Constitution have been violated by a public authority. The individual can file the claim in question only after having exhausted all legal means provided by law ${ }^{5}$. The individual submits his request through the authorized representative (lawyer) or even in person if he has sufficient legal knowledge to complete the necessary documentation.

But applicant has the duty to clarify in his request exactly which rights and freedoms he claims have been violated and what is the concrete act of the public authority which the applicant wants to challenge. At Constitutional Court the request is submitted within a period of four months. This deadline starts from the day when the applicant has been served with the court decision, so unlike other cases when the deadline starts to run on the day when the decision or act is publicly announced. If the request is directed against a law, then the deadline starts to run from the day the law entered into force ${ }^{6}$. The Court reiterates that the 4 (four) month period is of a preclusive nature and was established to ensure the principle of legal certainty by ensuring that claims submitted in accordance with the Constitution are reviewed within a reasonable time and that past decisions are not maybe consistently open to constitutional review. Until the procedure is completed before the Constitutional Court it may temporarily suspend the contested action or law, until a decision is made by the Court, if it considers that

\footnotetext{
4 Article 38 of law on KCL.

5 Article 47 parag: 2 of law on KCL.

6 Article 49 of law on KCL.
}

the application of the contested action or law may cause irreparable damage.

\section{Eligibility Criteria}

Right to go to court, of which the right of access is one aspect, but not absolute. It is subject to tacit restrictions, especially with regard to admissibility of a complaint, since it by its very nature requires regulation by the state, which enjoys a certain margin of appreciation in this regard. However, such restrictions shall not restrict or diminish the access of a person in such a manner or extent as to prejudice very essence of the law. Such restrictions are not in accordance with article $6 \S 1$ of ECHR, if they do not pursue the legitimate aim or if there is no reasonable relationship of proportionality between the means used and the aim pursued. Citizens often ask for information from various public authorities, but sometimes do not get answers to their questions. However, according to legal rules, every citizen has the right to receive information from public authorities [2].

Therefore, the Court first examines whether the applicant has met the admissibility criteria set out in the Constitution, the Law and the Rules of Work. For a request to be considered admissible and clearly grounded, it must meet these criteria:

a) The request is submitted by an authorized party;

b) Sll effective means provided by law against the contested decision or judgment have been exhausted;

c) The request is submitted within four months from the day of delivery of the decision of the last effective legal mean to the applicant.

Thus, individuals are authorized to raise violations by public authorities of their individual rights and freedoms, guaranteed by the Constitution, but only after they have exhausted all legal means provided by law. The principle of subsidiarity requires the applicant to exhaust all procedural possibilities in regular procedure, in order to prevent the violation of the Constitution, or, if there is a violation, to correct such violation of fundamental rights. Otherwise, the applicant is liable when his case is declared inadmissible by the Constitutional Court, if he or she fails to use regular procedures, or if he/she fails to report violations of the Constitution in regular procedure. This rule is based on the assumption that the legal order of the Republic of Kosovo provides effective legal means for protection against violations of constitutional rights [3-7].

\section{The Request is Clearly Unfounded or Even Inadmissible}

A claim will be assessed as clearly unfounded if: 
- The request is not justified prima facie

- The facts presented do not in any way justify the allegation of a violation of a constitutional right.

The Court finds that the applicant is not subject to any violation of the rights guaranteed by the Constitution. But the request can be considered inadmissible even in the following cases when:

- The court has no jurisdiction over the case

- The court has already issued a decision on the case in question and the request does not provide sufficient grounds for issuing a new decision.

- The request is not ratione materiae in accordance with the Constitution ${ }^{7}$.

The current legislation does not provide a clear picture of the extent of the constitutional review of court decisions by the Constitutional Court. However, the decisions of the Constitutional Court which declare the judgments of the Supreme Court unconstitutional must be respected and executed by the Supreme Court. Decisions of the Constitutional Court are binding on all natural persons and on public authorities, including the courts [1]. The strategic plan 2018-2020 of the Constitutional Court was compiled with the support of experts engaged by the German organization Deutsche Gesellschaft fur Internationale Zusammenarbeit (GIZ) GmbH, Kosovo Office.

\section{Conclusion}

Decisions of the Constitutional Court should be considered as the cornerstone for that part of the constitutional jurisprudence that deals with the issue of reopening criminal proceedings pursuant to a decision of the ECHR in favour of the applicant. With the authority to review legislation and individual claims for violations of rights, the Constitutional Court is the highest control over the legislative and executive power in Kosovo and is the highest arbiter for the interpretation of constitutional provisions for the protection of the human rights and freedoms. The citizens of Kosovo are increasingly learning to "fight" for the protection

7 Rule 36 parag. 3, (changed on 28 October 2014) of rule of KCL. of their human rights to the highest instances of the state.

The purpose of the constitutional process in this case is to repeal those court decisions that have led to the violation of a right and to enable the judiciary to act in the first place in accordance with its own security and freedom. Also is valuable the reference to the well-known principle that in relation to a fundamental right, observance of international obligations can never be the cause of a reduction of its protection in comparison with those already provided for by the internal order, but can and should, on the contrary, constitute an effective instrument of expanding self-defence. The Constitution of the Republic of Kosovo automatically implements international conventions related to human rights, therefore, on this are based the decisions of the Constitutional Court which is increasingly a reference point for the protection of these freedoms and rights for the citizens of this country.

\section{References}

1. Mushkolaj, Gjyljeta, Morina, Visar, Lameon, et al. (2014) Commentary law on the Constitutional Court of Kosovo. Prostina: GiZ Kosova.

2. Hasani, Enver, Čukalović, Ivan (2013) Commentary Constitutions of the Republic of Kosovo. Pristina: GIZ, Pristina.

3. (2008) Constitution of the Republic of Kosovo, Pristina, pp: 1-68.

4. European Convention on Human Rights as amended by Protocols No. 11 \& 14 supplemented by Protocols Nos. 1, $4,6,7,12,13$ and 16.

5. Law No. 03/L-121. On the Constitutional Court of Republic of Kosovo.

6. Rules of Procedure of the constitutional court of the Republic of Kosovo, No. 50/2015 3 March, 2015.

7. Judicial Practice and Bulletins of the Constitutional Court of Kosovo.

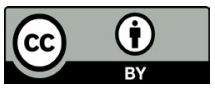

Uka M. Several Aspects of Procedures in Kosovo Constitutional Court Regarding Fair Trial. Ann Bioethics Clin App 2020, 3(3): 000135. 